\title{
Penoscrotal transposition
}

INSERM

\section{Source}

INSERM. (1999). Orphanet: an online rare disease and orphan drug data base.

Penoscrotal transposition. ORPHA:2842

Penoscrotal transposition (PST) is a rare congenital genital anomaly in which the scrotum is positioned superior and anterior to the penis. PST may present with a broad spectrum of anomalies ranging from simple shawl scrotum (doughnut scrotum) to very complex extreme transposition with craniofacial, central nervous system, cardiac, gastrointestinal, urological, and other genital (undescended testicles, hypospadias, chordee) malformations. Growth deficiency and intellectual disability may also be noticed (60\% of cases). 